\title{
Genetically modified $\alpha$-amylase inhibitor peas are not specifically allergenic in mice
}

\author{
D Reiner ${ }^{1 *}$, R Lee ${ }^{1}$, TJ Higgins ${ }^{2}$, MM Epstein ${ }^{1}$ \\ From Food Allergy and Anaphylaxis Meeting (FAAM 2013) \\ Nice, France. 7-9 February 2013
}

\section{Background}

Weevils can devastate food legumes in developing countries, but genetically modified peas (Pisum sativum), chickpeas and cowpeas expressing the gene for alpha-amylase inhibitor-1 ( $\alpha \mathrm{AI})$ from the common bean (Phaseolus vulgaris) are completely protected from weevil destruction. $\alpha \mathrm{AI}$ is seed-specific, accumulated at high levels and undergoes post-translational modification as it traverses the seed endomembrane system. This modification was thought to be responsible for the reported allergenicity in mice of the transgenic pea but not the bean.

\section{Methods}

To evaluate whether consumption of bean and $\alpha$ AI pea seed meals generated allergic responses to $\alpha \mathrm{AI}$, we fed mice $\alpha \mathrm{AI}$ transgenic peas, non-transgenic (nGM) peas, Tendergreen bean (sourse of $\alpha$ AI gene) and Pinto bean. MIce received raw or heat-treated seed meal diluted in PBS twice weekly for 4 consecutive weeks, followed by $50 \mu \mathrm{g}$ of $\alpha \mathrm{AI}$ i.n. We then measured allergic airway and lung inflammation, mucus hypersecretion and antibody production.

\section{Results}

In this study we observed that both the transgenic legumes and non-transgenic beans were allergenic in BALB/c mice. Even consuming non-transgenic peas lacking $\alpha \mathrm{AI}$ led to an anti- $\alpha \mathrm{AI}$ response due to a cross-reactive response to pea lectin. Our data demonstrate that $\alpha \mathrm{AI}$ transgenic peas are not more allergenic than beans or non-transgenic peas in mice.

\section{Conclusion}

This study illustrates the importance of repeat experiments in independent laboratories and the potential for unexpected crossreactive allergic responses upon consumption of plant products in mice.

\section{Disclosure of interest}

None declared.

\section{Author details}

${ }^{1}$ Department of Dermatology, Division of Immunology, Allergy and Infectious Diseases, Medical University of Vienna, Vienna, Austria.

${ }^{2}$ Plant Industry, CSIRO, Canberra, Australia.

Published: 25 July 2013

\section{doi:10.1186/2045-7022-3-S3-P84}

Cite this article as: Reiner et al:: Genetically modified $\alpha$-amylase inhibitor peas are not specifically allergenic in mice. Clinical and Translational Allergy 2013 3(Suppl 3):P84.
'Department of Dermatology, Division of Immunology, Allergy and Infectious Diseases, Medical University of Vienna, Vienna, Austria Full list of author information is available at the end of the article
Submit your next manuscript to BioMed Central and take full advantage of:

- Convenient online submission

- Thorough peer review

- No space constraints or color figure charges

- Immediate publication on acceptance

- Inclusion in PubMed, CAS, Scopus and Google Scholar

- Research which is freely available for redistribution

Submit your manuscript at www.biomedcentral.com/submit
() Biomed Central 